\title{
Effects of egg size, food supply and spawning time on early life history success of haddock Melanogrammus aeglefinus
}

\author{
R. M. Rideout ${ }^{1,2,3, *}$, E. A. Trippel ${ }^{1}$, M. K. Litvak ${ }^{2}$ \\ ${ }^{1}$ Biological Station, Fisheries and Oceans Canada, 531 Brandy Cove Road, St. Andrews, New Brunswick E5B 2L9, Canada \\ ${ }^{2}$ Department of Biology and Centre for Coastal Studies and Aquaculture, University of New Brunswick Saint John, \\ New Brunswick E2L 4L5, Canada
}

${ }^{3}$ Present address: Fisheries Conservation Group, Marine Institute of Memorial University of Newfoundland, PO Box 4920 , St. John's, Newfoundland A1C 5R3, Canada

\begin{abstract}
Eggs and larvae produced by pairs of spawning haddock Melanogrammus aeglefinus were monitored between 2001 and 2003 to determine the effects of spawning time, egg size and food supply on early life history success. Females usually released eggs at 3 d intervals. All females exhibited a continuous decrease in egg diameter and dry weight with consecutive batches, but the decrease in size did not influence fertilization or hatching success. Larval size (standard length and dry weight), yolk area, eye diameter, myotome height, and finfold area were all positively related to egg size and therefore decreased between early- and late-season larvae produced by the same spawning pairs. Differences in larval morphology persisted for at least the first $5 \mathrm{~d}$ after hatching. Jaws were not developed at hatching $\left(5^{\circ} \mathrm{C}\right)$, but jaw length did show a strong positive relationship with egg size at $5 \mathrm{~d}$ post-hatch (dph). The ability of newly hatched larvae to withstand periods of starvation was directly related to initial egg size. Under high prey abundance $\left(5000 \mathrm{l}^{-1}\right)$ larval survival to $20 \mathrm{dph}$ was highly variable (1.8 to $50.7 \%$ ) with no differences in survivorship or specific growth rate ( 0.818 to $0.936 \% \mathrm{~d}^{-1}$ in standard length) for larvae from early-, middle- and late-season egg batches. With low prey density $\left(1000 \mathrm{l}^{-1}\right)$ survival of larvae from late-season egg batches was significantly lower $(0.4 \%)$ than those from early egg batches $(1.8 \%)$. No differences in larval specific growth rate existed between early and late batches, but growth rate was reduced in both cases with low food abundance (0.683 to $0.690 \mathrm{~d}^{-1}$ in standard length). Results suggest that smaller larvae produced late in the spawning season have reduced feeding capabilities and may experience lower survivorship in the ocean than larger, early-season larvae.
\end{abstract}

KEY WORDS: Haddock · Spawning time $\cdot$ Egg size $\cdot$ Larvae $\cdot$ Prey density $\cdot$ Early life history success · Recruitment

Resale or republication not permitted without written consent of the publisher

\section{INTRODUCTION}

The 'bigger is better' hypothesis suggests that body size is a key component in the early life history success of fishes. Larger eggs produce larger larvae at hatch and larger body size infers a survival advantage due to an increased ability to find and capture prey, endure periods of low food abundance and avoid predation (see Heyer et al. 2001, Ouellet et al. 2001, Browman et al. 2003 and references therein).

Analysis of otoliths from wild larvae suggests that larger individuals do experience a survival advantage over smaller counterparts (Meekan \& Fortier 1996). However, apart from Wallace \& Aasjord's (1984) report that Arctic charr Salvelinus alpinus from large eggs suffered less initial mortality than those from small eggs, 
direct experimental evidence to support the claim that larger larvae experience a survival advantage over smaller counterparts is generally lacking (Zonova 1973, Thorpe et al. 1984, Springate \& Bromage 1985, Pepin 1991, Gisbert et al. 2000, Jónsson \& Svavarsson 2000, Ouellet et al. 2001). Egg and larval size may be important for survival under competitive conditions, such as those that prevail in wild fish stocks, but not under high-prey conditions such as those in hatcheries (Hutchings 1991, McEvoy \& McEvoy 1991, Gisbert et al. 2000, Jónsson \& Svavarsson 2000).

Much of the evidence to support the claim that larvae from large eggs have a survival advantage over those from small eggs comes from food-deprivation studies, which do not necessarily measure 'survival' but rather 'time taken to die'. Larvae from large eggs have larger yolk reserves than those from small eggs and survive longer without food (Heyer et al. 2001, Ouellet et al. 2001, Browman et al. 2003). Thus, it is speculated that in environments with highly variable prey abundance (i.e. intermittent periods of high and low food density), larvae from large eggs will have a greater probability of survival than those from small eggs.

Much of the current knowledge concerning reproduction and early life history success in fishes is based on work with cultured species. As a result, much more is known about reproduction in salmonids than in marine fishes. Salmonids spawn a single batch of eggs per year and therefore studies examining the effects of egg size on early life history success (e.g. Thorpe et al. 1984, Wallace \& Aasjord 1984, Ojanguren et al. 1996) have had to rely on eggs from different females, often of different size and age and from different strains and/or geographical locations. In such cases, the relationship between progeny size and early life history traits may be confounded by genetic factors.

Fishes that are serial spawners release several discrete 'batches' of eggs, with egg size often decreasing between successive batches (Hinckley 1990, McEvoy \& McEvoy 1991, Ouellet et al. 2001). The decrease in egg size has been attributed to decreasing energy reserves in spawning females (Houghton et al. 1985, Bromley et al. 1986, Kjesbu et al. 1990) or the increase in temperature that occurs late in the spawning season for spring-summer spawning species (Ware 1975, Tanasichuk \& Ware 1987, Chambers 1997). Whatever the cause, the decrease in egg size from a single female allows the effect of egg size on early life history success to be evaluated without the confounding effect of maternal genetics. By placing an individual female in a spawning tank with a single male, the confounding effect of paternal genetics (Rideout et al. 2004a) can also be negated. In this paper, we use the pairedspawning setup to examine changes in haddock,
Melanogrammus aeglefinus, egg size throughout the spawning season and the effect that egg size has on larval morphology and early life history success.

\section{MATERIALS AND METHODS}

Broodstock husbandry. Haddock broodstock were collected from the Bay of Fundy in October 2000 and transported to communal holding tanks $\left(36 \mathrm{~m}^{3}\right)$ at the St. Andrews Biological Station. Fish were maintained on a diet of frozen mackerel Scomber scombrus, herring Clupea harengus and squid Ilex illecebrosus throughout the year, but refused food several weeks prior to the initiation of spawning and were not fed again until spawning was completed.

In 2001, 2002 and 2003, before the onset of spawning, all fish were weighed and checked for signs of running gametes or other indicators of impending spawning (i.e. distended abdomens in females) and then moved to smaller paired-mating tanks (diameter $2 \mathrm{~m}$, depth $1.5 \mathrm{~m}$, volume $3.5 \mathrm{~m}^{3}$ ) based on sex and reproductive status. We set up 9 spawning pairs in 2001, 5 pairs in 2002 and 3 pairs in 2003. Attempts were made to match males and females of approximately equal size (Table 1) since large differences in body size could lead to a reduction in fertilization success (Rakitin et al. 2001). A mixture of ambient and heated seawater (30 ppt) was used to keep the water temperature in the spawning tanks at 5 to $6^{\circ} \mathrm{C}$ throughout the entire spawning season.

Egg collection and incubation. Before placing fish in paired-mating tanks, each tank was equipped with an in-tank collector designed to collect floating eggs as well as a drain collector to collect eggs that sank to the bottom of the tank. Egg collectors were checked on a daily basis and eggs were transferred to a plastic 31 beaker containing cold seawater using a fine-meshed net.

Using a stereomicroscope (Olympus 30 to $40 \times$ ), all egg batches from 2001 and 2002 were analyzed for size and fertilization success. Eggs collected in 2003 were used only to produce larvae for feeding trials (i.e. egg size, fertilization success, hatching success and larval morphology were not determined). Egg batches with no visible cleavage were placed in a refrigerator for 2 to $3 \mathrm{~h}$ and then rechecked to allow for the possibility that the eggs had been collected prior to the first cleavage of the blastodisc. A digital camera (Pixera Pro 150 ES, Pixera Corporation) attached to the microscope was used to capture digital images of eggs and imageanalysis software (Optimas 6.2, BioScan) was used to determine mean egg diameters for 75 to 100 eggs from each batch. A preliminary analysis revealed no difference in diameter between unfertilized eggs and 
Table 1. Melanogrammus aeglefinus. Weight and length data for haddock spawning pairs used in 2001 to 2003 . Pair numbers correspond to numbers in parentheses in Fig. 1. K: Fulton's $K$

\begin{tabular}{|c|c|c|c|c|c|c|c|c|}
\hline \multirow{2}{*}{ Pair no. } & \multirow{2}{*}{ Year } & \multirow{2}{*}{ Sex } & \multicolumn{3}{|c|}{ Pre-spawning } & \multicolumn{3}{|c|}{ Post-spawning } \\
\hline & & & Length $(\mathrm{cm})$ & Weight (g) & $K$ & Length $(\mathrm{cm})$ & Weight (g) & $K$ \\
\hline \multirow[t]{2}{*}{1} & \multirow[t]{2}{*}{2001} & $\mathrm{~F}$ & 54.5 & 2331 & 1.440 & 54.8 & 2006 & 1.219 \\
\hline & & M & 47.4 & 1315 & 1.235 & 47.6 & 1167 & 1.082 \\
\hline \multirow[t]{2}{*}{$2^{\mathrm{a}}$} & \multirow[t]{2}{*}{2001} & $\mathrm{~F}$ & 56.7 & 2737 & 1.502 & 56.9 & 2238 & 1.215 \\
\hline & & M & 53.1 & 1743 & 1.164 & 53.5 & 1511 & 0.987 \\
\hline \multirow[t]{2}{*}{$3^{\mathrm{ab}}$} & \multirow[t]{2}{*}{2001} & $\mathrm{~F}$ & 53.4 & 1928 & 1.266 & 53.5 & 1625 & 1.061 \\
\hline & & M & 47.6 & 1331 & 1.234 & 47.8 & 1298 & 1.188 \\
\hline \multirow[t]{2}{*}{$4^{\mathrm{ab}}$} & \multirow[t]{2}{*}{2001} & $\mathrm{~F}$ & 48.5 & 1626 & 1.425 & 48.8 & 1260 & 1.084 \\
\hline & & $\mathrm{M}$ & 47.3 & 1228 & 1.160 & 47.5 & 1112 & 1.038 \\
\hline \multirow[t]{2}{*}{5} & \multirow[t]{2}{*}{2001} & $\mathrm{~F}$ & 55.5 & 2257 & 1.320 & 55.6 & 1986 & 1.155 \\
\hline & & $\mathrm{M}$ & 52.8 & 1838 & 1.249 & 53.1 & 1682 & 1.123 \\
\hline \multirow[t]{2}{*}{$6^{a}$} & \multirow[t]{2}{*}{2001} & $\mathrm{~F}$ & 59.9 & 2969 & 1.381 & 60.0 & 2605 & 1.206 \\
\hline & & M & 55.5 & 1899 & 1.111 & 55.7 & 1712 & 0.991 \\
\hline \multirow[t]{2}{*}{7} & \multirow[t]{2}{*}{2001} & $\mathrm{~F}$ & 57.8 & 2443 & 1.265 & 57.8 & 2021 & 1.047 \\
\hline & & M & 52.4 & 1951 & 1.356 & 52.6 & 1794 & 1.233 \\
\hline \multirow[t]{2}{*}{8} & \multirow[t]{2}{*}{2001} & $\mathrm{~F}$ & 56.9 & 2613 & 1.418 & 57.0 & 1935 & 1.045 \\
\hline & & M & 54.4 & 2042 & 1.268 & 54.8 & 1788 & 1.086 \\
\hline \multirow[t]{2}{*}{9} & \multirow[t]{2}{*}{2001} & $\mathrm{~F}$ & 57.4 & 2380 & 1.258 & 57.6 & 1674 & 0.876 \\
\hline & & M & 53.9 & 1982 & 1.266 & 54.2 & 1635 & 1.027 \\
\hline \multirow[t]{2}{*}{10} & \multirow[t]{2}{*}{2002} & $\mathrm{~F}$ & 63.9 & 3948 & 1.513 & 64.0 & 3312 & 1.263 \\
\hline & & M & 56.7 & 2613 & 1.433 & 57.1 & 2362 & 1.269 \\
\hline \multirow[t]{2}{*}{11} & \multirow[t]{2}{*}{2002} & $\mathrm{~F}$ & 62.5 & 3603 & 1.476 & 62.7 & 2988 & 1.212 \\
\hline & & M & 57.0 & 2459 & 1.328 & 57.3 & 2633 & 1.400 \\
\hline 12 & 2002 & $\mathrm{~F}$ & 43.5 & 1297 & 1.576 & 43.5 & 1125 & 1.367 \\
\hline & & M & 47.9 & 1513 & 1.377 & 48.3 & 1343 & 1.192 \\
\hline 13 & 2002 & $\mathrm{~F}$ & 44.8 & 1375 & 1.529 & 45.1 & 1120 & 1.221 \\
\hline & & M & 43.9 & 1073 & 1.268 & 44.1 & 940 & 1.096 \\
\hline 14 & 2002 & $\mathrm{~F}$ & 46.0 & 1570 & 1.613 & 46.5 & 1194 & 1.188 \\
\hline & & M & 44.2 & 1274 & 1.475 & 44.4 & 1086 & 1.241 \\
\hline 15 & 2003 & $\mathrm{~F}$ & 48.1 & 1612 & 1.449 & 48.0 & 1331 & 1.204 \\
\hline & & M & 49.2 & 1590 & 1.335 & 49.1 & 1274 & 1.076 \\
\hline 16 & 2003 & $\mathrm{~F}$ & 45.5 & 1470 & 1.561 & 45.8 & 1091 & 1.136 \\
\hline & & M & 47.0 & 1234 & 1.189 & 47.4 & 1073 & 1.008 \\
\hline 17 & 2003 & $\mathrm{~F}$ & 48.4 & 1796 & 1.584 & 48.3 & 1313 & 1.165 \\
\hline & & $\mathrm{M}$ & 46.5 & 1700 & 1.691 & 46.5 & 1423 & 1.425 \\
\hline
\end{tabular}

embryos (i.e. fertilized eggs) up to $2 \mathrm{~d}$ post-fertilization (paired $t$-test; $\mathrm{df}=9, t=0.937, \mathrm{p}=0.373$ ), and therefore slight differences in embryo developmental stage upon collection were not of concern when determining egg size. A sample of 2 to $10 \mathrm{ml}$ of embryos from each batch was fixed in $5 \%$ formalin for dry weight analysis.

A wide-mouthed pipette was used to transfer 250 to 300 embryos to $250 \mathrm{ml}$ beakers filled with UV-sterilized seawater (30 ppt). We set up 5 replicate beakers for each egg batch. All embryos were incubated at $5^{\circ} \mathrm{C}$. A complete water change was performed at 3 to $4 \mathrm{~d}$ post-fertilization (dpf), and a 50\% water change every second day thereafter. Mortalities and hatched larvae were removed and enumerated on a daily basis.

Larval morphology and performance. Larvae from a total of 51 egg batches spawned in 2001 and 2002 (3 to 7 batches per spawning pair) were analyzed for morphology. Egg batches were categorized as early (batches 1 to 5), middle (batches 5 to 10) and late (batches 10+) and statistical comparisons were made using these categories (Rideout et al. 2004b). At $5^{\circ} \mathrm{C}$, haddock embryos hatch over about an $8 \mathrm{~d}$ period but the majority of hatching occurs over 1 to $2 \mathrm{~d}$ (Rideout et al. 2004a). The day with the highest number of hatchings is referred to as the peak (or modal) hatch. Only larvae from the day of peak hatch were used for morphological comparisons.

Larvae from each beaker were processed as follows: (1) digital images were taken of 20 larvae on the day of hatch, after which the larvae were fixed in $5 \%$ formalin; (2) 20 larvae were allocated to a $100 \mathrm{ml}$ beaker of seawater $\left(5^{\circ} \mathrm{C}, 30 \mathrm{ppt}\right)$ and used to determine time to starvation; (3) 25 to 30 larvae were placed in a second $100 \mathrm{ml}$ beaker and left until $5 \mathrm{dph}$, at which time digi- 
tal images were captured of 20 larvae, followed by formalin fixation. Dry weights of eggs and larvae were determined using material that had been fixed in formalin for 6 mo. Prior to drying, egg and larval samples were soaked in diluted acetic acid and rinsed with distilled water as per Trippel (1998) to remove all formalin residues. Mean dry weights $( \pm 1 \mu \mathrm{g})$ were determined by drying 3 replicates of eggs (30 per replicate) and larvae ( 3 per replicate beaker) per batch at $60^{\circ} \mathrm{C}$ for $48 \mathrm{~h}$ and then dividing the weight by the number of individuals per replicate.

The following larval morphological measurements were made: (1) standard length (SL), distance from tip of snout to tip of notochord; (2) myotome height, taken immediately posterior to anus; (3) jaw length; (4) eye diameter; (5) yolk area; (6) finfold area. For each beaker, morphological measurements for the 20 larvae were averaged to give a single value for each morphological character for each replicate.

Larvae in the starvation beakers were monitored on a daily basis and mortalities removed as soon as they were observed. Dead larvae were inspected under a stereomicroscope for the presence of yolk. If yolk was still present, the larva was assumed to have died from causes other than starvation and was eliminated from the study. Time taken to reach 50 and $95 \%$ mortality were calculated for each beaker.

Feeding trials. Larvae were reared in $40 \mathrm{l}$ glass aquaria with water temperature maintained at $7^{\circ} \mathrm{C}$. The sides of the aquaria were covered with black plastic, while white plastic was placed under the aquaria to achieve upwelling light (Downing \& Litvak 1999a). Water in the aquaria was 'greened' with the alga Isochrysis sp. (Tahitian strain [T-ISO]; 50000 cells ml $^{-1}$ culture water feeding ${ }^{-1}$ ) prior to adding larvae. Larvae were fed twice daily with a mixture of alga Isochrysis sp. (T-ISO; 20000 cells ml $^{-1}$ culture water feeding $^{-1}$ ) and the rotifer Branchionus plicatilis. Rotifers were reared on a combination of Rotimac ${ }^{\circledR}$ (Aquafauna Bio-Marine) and algae. Overflows from the aquaria were filtered to $200 \mu \mathrm{m}$ with a banjo-type filter. An airstone in each aquarium helped keep rotifers and larvae circulating, but was carefully adjusted so as not to interfere with larval swimming and feeding. Algae and rotifers that did settle to the bottom were siphoned off on a regular basis.

Feeding and experimental conditions differed between the 2001 and 2002 experiments and the 2003 experiment, causing the 2003 experiment to be analyzed separately while experiments from 2001 and 2002 were analyzed together. In both 2001 and 2002, 500 larvae from an early-, middle- and late-season egg batch from each spawning pair were counted into 3 replicate aquaria. Light intensity (incandescent) was kept at 80 lux and maintained $24 \mathrm{~h} \mathrm{~d}^{-1}$. All larvae were fed at a high prey level (5000 rotifers $\mathrm{l}^{-1}$ culture water feeding $\left.{ }^{-1}\right)$. Inadequate temperature control of incoming seawater did not allow a continuous flow of water through the aquaria. Instead, twice daily, a header tank within the temperature-controlled room was filled with seawater and left until the water temperature reached $7^{\circ} \mathrm{C}$, at which point it was flushed through the aquaria. The result was a complete exchange of water in the aquaria twice each day. In 2003, 1000 larvae from an early- and late-season egg batch from each spawning pair were counted into 6 replicate aquaria. Light intensity (incandescent) was 110 lux and was $24 \mathrm{~h} \mathrm{~d}^{-1}$. For larvae from each egg batch, 3 aquaria were supplied with a high food ration (5000 rotifers $\mathrm{l}^{-1}$ culture water feeding ${ }^{-1}$ ) and three aquaria were fed at a low food ration (1000 rotifers $\mathrm{l}^{-1}$ culture water feed$\mathrm{ing}^{-1}$ ). Water supply was continuous (i.e. flow-through) at $100 \mathrm{ml} \mathrm{min}^{-1}$, resulting in 5.76 complete water exchanges each day in each aquarium.

Feeding experiments were terminated at $20 \mathrm{dph}$ and all larvae were killed using an excess of tricaine methanesulphonate (MS-222, Syndel). Larvae in each aquarium were counted in order to determine survivorship. Larvae were fed approximately $1 \mathrm{~h}$ before being killed so that feeding individuals could easily be distinguished from those that were starving. Starving larvae were not counted as survivors. Digital images were taken of all larvae remaining at the end of the feeding trials and larval standard lengths were determined using image-analysis software (Optimas 6.2, BioScan). Specific growth rates $\left(G_{\mathrm{s}}\right)$ over the experimental period were determined as:

$$
G_{\mathrm{s}}=\frac{\left(\ln L_{2}-\ln L_{1}\right)}{\left(t_{2}-t_{1}\right)} \times 100 \%
$$

where $L$ is standard length at time $t_{1}(0 \mathrm{dph})$ and $t_{2}$ (20 dph).

Statistical analysis. Prior to analyses, data were examined for normality and heterogeneity of variances and log-transformed when necessary. Percentage data were arcsine square-root transformed. Morphological characters (i.e. standard length, myotome height, jaw length, eye diameter and finfold area) of larvae from early-, mid- and late-season egg batches were compared at 0 and $5 \mathrm{dph}$ using repeated-measures analyses of variance (ANOVA) based on mean values per batch. Relative batch interval frequencies were determined and the fertilization success of egg batches released at the end of each interval was compared between batch intervals using a single-factor ANOVA. The effect of batch number on time to peak hatch was explored with least-squares linear regression. All a posteriori tests were performed using Tukey's multiple-comparisons test. Significance levels were set at $p=0.05$ for main effects and $p=0.2$ for interactions in order to minimize the probability of a Type II error (Winer 1971). 


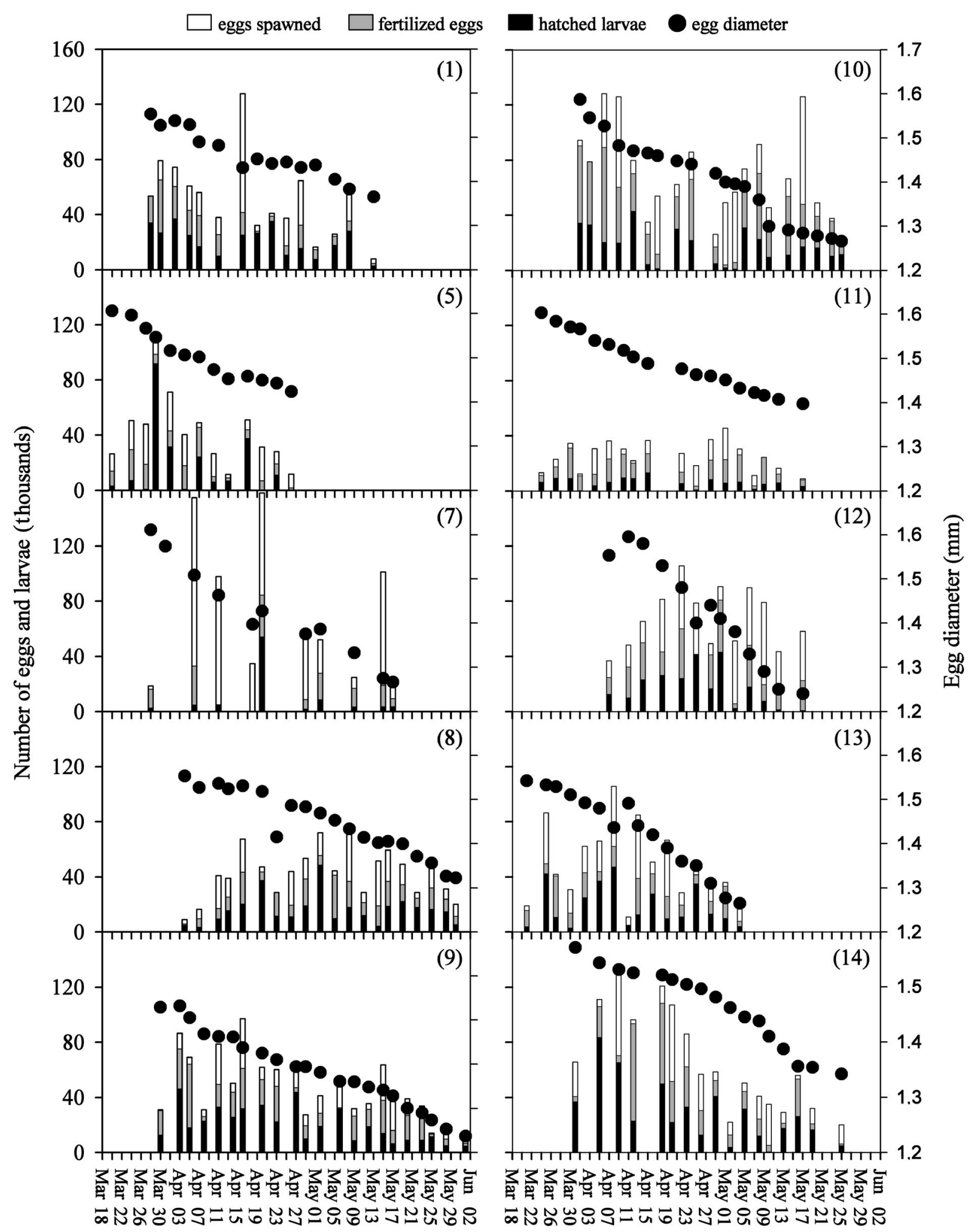

Date of spawning

Fig. 1. Melanogrammus aeglefinus. Spawning characteristics of 10 haddock pairs maintained at 5 to $6^{\circ} \mathrm{C}$. Graphs on left represent spawning pairs from 2001, graphs on right from 2002. Spawning pair number (see Table 1) is indicated in upper right-hand corner of each graph. Data from pairs that produced only unfertilized egg batches are not shown 
Data from all spawning pairs were pooled (as if eggs were collected from a communal spawning tank) in order to investigate the effects of egg size on early life history traits. Least-squares linear regression was used to determine the relationships between egg diameter and hatching success, fertilization success, egg dry weight, larval standard length, myotome height, jaw length, eye diameter, finfold area and time to 50 and $95 \%$ mortality due to starvation. Relationships between egg diameter and larval morphological traits were investigated for larvae on 0 and $5 \mathrm{dph}$ with significance levels set at $\mathrm{p}=0.05$.

Survival and specific growth rate between early-, mid- and late-season egg batches in 2001 and 2002 were compared using single-factor repeated-measures ANOVA. Survival and growth data for 2003 were compared between early- and late-season egg batches at low and high food levels using a 2-factor repeatedmeasures ANOVA.

\section{RESULTS}

Of the 9 haddock pairs set up in 2001, 4 did not spawn, whereas all pairs spawned successfully in 2002 and 2003; 2 of the females that did not spawn died towards the end of the spawning season. These females had hugely distended abdomens due to the presence of large numbers of coalesced hydrated oocytes in the ovarian lumen, which prevented the release of any further batches. Until their death, these females, along with the other 2 non-spawning

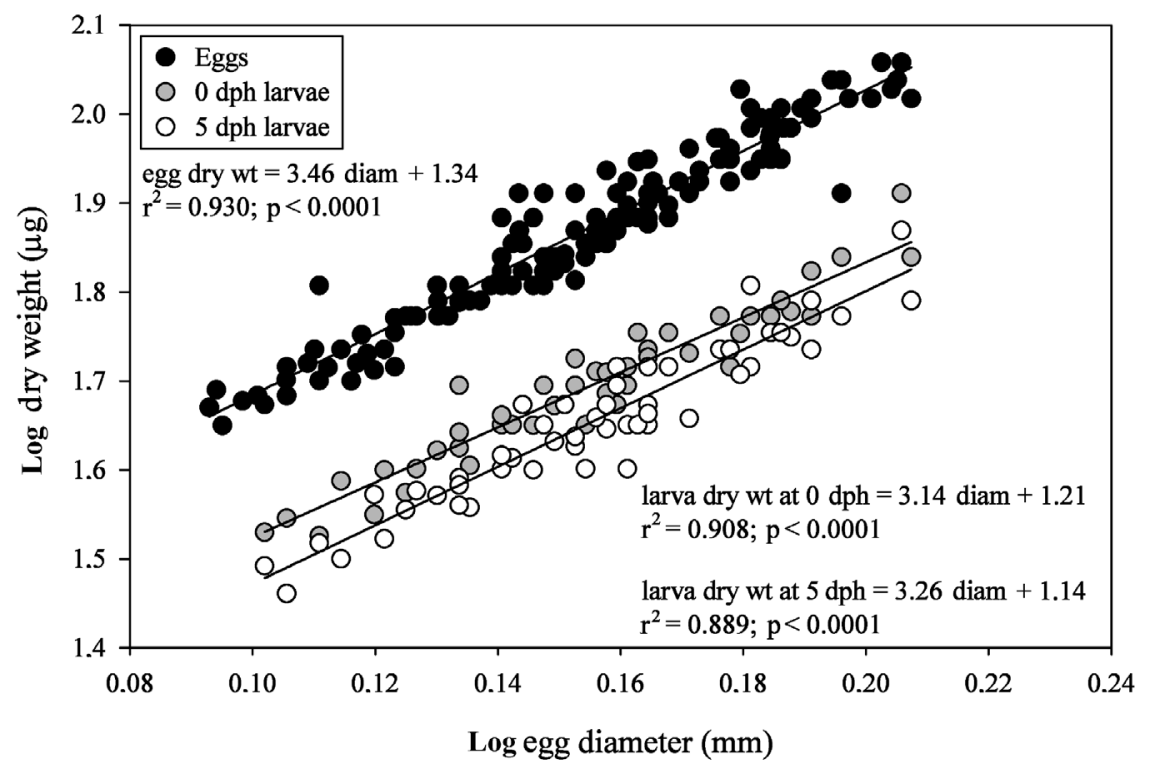

Fig. 2. Melanogrammus aeglefinus. Relationship between egg diameter and egg dry weight as well as larval dry weight (wt) at 0 and $5 \mathrm{~d}$ post-hatch (dph) females, sporadically released large batches of eggs (up to 182000 eggs) 1 to $3 \mathrm{wk}$ apart that were very clumped together and which failed to be fertilized. Egg size declined throughout the spawning season for all haddock pairs that did spawn successfully (Fig. 1). Egg dry weight was positively related to egg diameter (Fig. 2) and decreased by 31.6 to $54.3 \%$ (mean $43.8 \%$ ) between first and final egg batch for each spawning pair. Batch fecundity ranged from 8240 to 79000 and was inversely related to batch number (Table 2). As a result, total egg batch dry weight also demonstrated a negative relationship with batch number (Table 2).

The interval between batches for haddock spawning pairs was not related to batch number $(p=$ 0.6418). The modal batch interval at 5 to $6^{\circ} \mathrm{C}$ was $3 \mathrm{~d}$ (Fig. 3). Individual haddock never spawned on consecutive days. Variability in fertilization success was greater following batch intervals of 5 to $7 \mathrm{~d}$ than with lower or higher batch intervals. Intervals greater than $7 \mathrm{~d}$ resulted in lower fertilization success than intervals $\leq 7 \mathrm{~d}$ (Fig. $3 ; \mathrm{p}<0.001$ ). Fertilization and hatching success were highly variable among spawning pairs and among batches (Fig. 1) and neither was significantly related $(p>0.05)$ to batch number (Table 2$)$. The modal time taken to reach peak hatch was $18 \mathrm{~d}$ and was unaffected by batch number $(\mathrm{p}=0.8113$; Table 2).

All larval morphological traits (standard length, myotome height, eye diameter, jaw length, yolk area and finfold area) differed significantly $(\mathrm{p}<0.05)$ between early-, mid- and late-season egg batches. All traits at 0 and $5 \mathrm{dph}$ were positively related to egg diameter (Fig. 4).

In $<2 \%$ of cases the proportion of larvae that died within the first $3 \mathrm{~d}$ after hatching (i.e. before yolk reserves were depleted) was as high as $20 \%$, but in the remainder of cases was $<5 \%$. Larvae that were deemed to have died from starvation (i.e. no yolk) were collected between 9 and $23 \mathrm{dph}$. Time to 50 and $95 \%$ mortality showed a strong positive relationship with egg diameter (Fig. 5).

Survival to 20 dph was highly variable in 2001 and 2002 (1.8 to $50.7 \%$ ), with no significant difference $(\mathrm{p}=$ 0.546) in survival between larvae from early-, mid- and late-season egg batches (Fig. 6a). A significant interaction between spawning time and feeding level existed for the 2003 survival data (Fig. 6b). As a result, a single-factor ANOVA was used to compare all 
Table 2. Melanogrammus aeglefinus. Mean $( \pm$ SE) egg-batch characteristics for the 10 pairs of spawning haddock used in 2001 and 2002. DW: dry weight; $\mathrm{n}$ : number of spawning pairs

\begin{tabular}{|lcccccc|}
\hline Batch & $\mathrm{n}$ & $\begin{array}{c}\text { Batch fecundity } \\
\text { (thousands) }^{\mathrm{a}}\end{array}$ & $\begin{array}{c}\text { Batch DW } \\
(\mathrm{g})^{\mathrm{b}}\end{array}$ & $\begin{array}{c}\text { Fertilization } \\
\text { success }(\%)\end{array}$ & $\begin{array}{c}\text { Hatching } \\
\text { success }(\%)\end{array}$ & $\begin{array}{c}\text { Time to peak hatch } \\
(\mathrm{d})\end{array}$ \\
\hline 1 & 10 & $36.7 \pm 8.5$ & $2.01 \pm 0.01$ & $79.9 \pm 5.3$ & $49.2 \pm 8.0$ & $17.7 \pm 0.9$ \\
2 & 10 & $58.0 \pm 11.4$ & $1.98 \pm 0.02$ & $73.4 \pm 5.5$ & $50.4 \pm 6.3$ & $18.0 \pm 1.0$ \\
3 & 10 & $79.0 \pm 13.8$ & $1.96 \pm 0.02$ & $66.4 \pm 8.3$ & $38.3 \pm 8.2$ & $18.0 \pm 1.2$ \\
4 & 10 & $68.2 \pm 12.2$ & $1.95 \pm 0.02$ & $65.1 \pm 9.0$ & $53.6 \pm 10.2$ & $17.4 \pm 1.6$ \\
5 & 10 & $70.7 \pm 8.9$ & $1.93 \pm 0.02$ & $60.3 \pm 8.1$ & $46.7 \pm 6.6$ & $18.4 \pm 1.4$ \\
6 & 10 & $65.7 \pm 12.6$ & $1.91 \pm 0.02$ & $65.2 \pm 5.1$ & $52.1 \pm 10.0$ & $16.8 \pm 1.7$ \\
7 & 10 & $68.4 \pm 10.6$ & $1.87 \pm 0.02$ & $63.0 \pm 9.7$ & $44.5 \pm 6.0$ & $17.7 \pm 1.3$ \\
8 & 10 & $45.9 \pm 7.5$ & $1.87 \pm 0.02$ & $67.7 \pm 7.0$ & $59.4 \pm 6.3$ & $19.2 \pm 1.6$ \\
9 & 10 & $50.8 \pm 7.5$ & $1.87 \pm 0.03$ & $69.1 \pm 7.7$ & $51.7 \pm 7.2$ & $18.1 \pm 0.6$ \\
10 & 10 & $54.2 \pm 8.7$ & $1.84 \pm 0.04$ & $61.3 \pm 6.5$ & $55.0 \pm 8.6$ & $17.2 \pm 1.4$ \\
11 & 10 & $45.0 \pm 6.6$ & $1.83 \pm 0.01$ & $46.5 \pm 9.3$ & $38.3 \pm 6.1$ & $18.3 \pm 0.8$ \\
12 & 9 & $40.4 \pm 5.4$ & $1.85 \pm 0.01$ & $57.6 \pm 7.4$ & $44.1 \pm 6.4$ & $18.0 \pm 1.2$ \\
13 & 9 & $41.4 \pm 6.2$ & $1.83 \pm 0.01$ & $59.2 \pm 10.3$ & $44.3 \pm 12.1$ & $18.5 \pm 1.2$ \\
14 & 7 & $46.4 \pm 8.5$ & $1.81 \pm 0.01$ & $69.1 \pm 6.3$ & $47.6 \pm 9.7$ & $17.8 \pm 0.9$ \\
15 & 7 & $35.9 \pm 7.6$ & $1.79 \pm 0.01$ & $71.3 \pm 8.4$ & $45.4 \pm 5.1$ & $18.0 \pm 1.1$ \\
16 & 6 & $43.3 \pm 7.8$ & $1.79 \pm 0.01$ & $68.0 \pm 9.3$ & $46.0 \pm 9.8$ & $18.6 \pm 0.5$ \\
17 & 5 & $45.6 \pm 20.4$ & $1.77 \pm 0.01$ & $55.0 \pm 10.7$ & $55.4 \pm 8.5$ & $18.2 \pm 1.0$ \\
18 & 4 & $36.3 \pm 9.4$ & $1.75 \pm 0.01$ & $76.6 \pm 5.3$ & $42.2 \pm 3.6$ & $17.7 \pm 1.8$ \\
19 & 3 & $34.2 \pm 1.9$ & $1.71 \pm 0.01$ & $82.8 \pm 6.1$ & $42.1 \pm 10.3$ & $18.9 \pm 1.3$ \\
20 & 3 & $17.8 \pm 1.9$ & $1.71 \pm 0.02$ & $84.9 \pm 13.9$ & $64.7 \pm 10.8$ & $18.2 \pm 1.7$ \\
21 & 1 & 16.6 & 1.68 & 60.0 & 52.0 & 17.0 \\
22 & 1 & 8.2 & 1.67 & & & 71.1 \\
$\mathrm{a} y=-2.23 x+71.59 ; \mathrm{r}^{2}=0.644 ; \mathrm{p}<0.0001$ & & & & 18.0 \\
$\mathrm{~b} y=-01 x+2.00 ; \mathrm{r}^{2}=0.757 ; \mathrm{p}<0.0001$ & & & & & \\
\hline
\end{tabular}

spawning time-food level combinations and a Tukey's multiple comparisons test was used for a posteriori analysis. Larvae experienced higher survivorship $(\mathrm{p}<$ 0.05) with the high prey density than the low prey den-

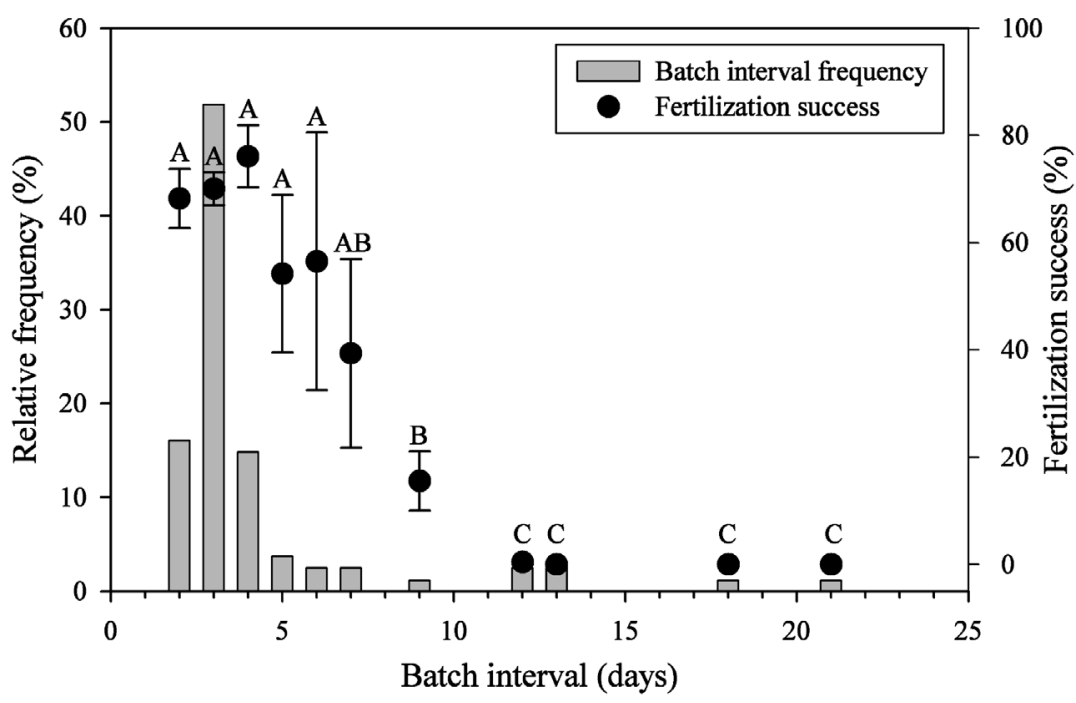

Fig. 3. Melanogrammus aeglefinus. Relative frequency of interval between batches and relationship between batch interval and fertilization success of subsequent egg batch. Batch number symbols with same letter are not significantly different. Error bars $= \pm 1 \mathrm{SE}$ sity (Fig. 6b). There was no significant difference $(\mathrm{p}>$ 0.05 ) in survival between larvae from early- and lateseason egg batches at the high food level. At the reduced food level, survivorship was lower $(p<0.05)$ for larvae from late-season egg batches than for early batches.

In 2001 and 2002, standard length of larvae was significantly different $(p<0.05)$ between early-, mid- and late-season egg batches at the start and end of the study period (Fig. 6c) and specific growth rate (0.818 to $0.923 \% \mathrm{~d}^{-1}$ in standard length) did not differ between batch times $(\mathrm{p}=$ 0.391). In 2003, larval standard lengths were different $(p<0.05)$ between earlyand late-season egg batches at the start and end of the $20 \mathrm{~d}$ feeding period for both prey densities (Fig. 6d). Specific growth rates were significantly lower $(p=0.011)$ for larvae with reduced prey abundance (0.683 to $0.690 \% \mathrm{~d}^{-1}$ in standard length) than those with high prey abundance (0.878 to $0.936 \% \mathrm{~d}^{-1}$ in standard length) for both early- and late-season egg batches, but did not differ $(p=0.811)$ between larvae from early- and lateseason batches at either prey density. 

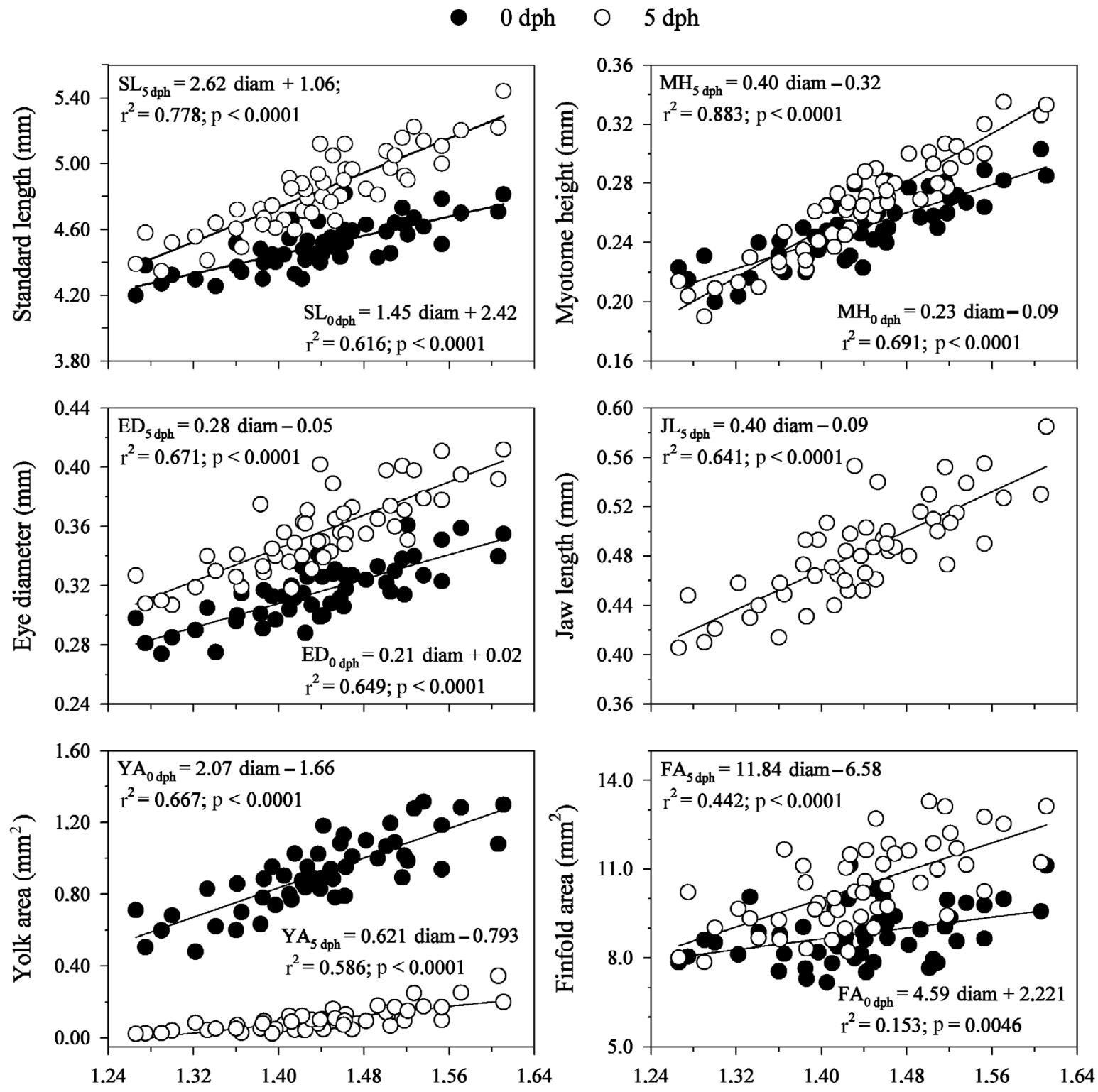

Egg diameter (mm)

Fig. 4. Melanogrammus aeglefinus. Relationships between egg diameter and larval morphological traits at 0 and 5 dph for larvae incubated at $5^{\circ} \mathrm{C}$

\section{DISCUSSION}

Haddock eggs from individual females decreased in diameter between first and final egg batches, a phenomenon previously reported for North Sea haddock (Hislop et al. 1978) as well as many other serial spawners (Hislop 1975, Kjesbu 1989, Hinckley 1990, McEvoy \& McEvoy 1991, Trippel 1998, Ouellet et al. 2001). Egg dry weight was highly correlated with egg diameter, suggesting that the reduction in egg size did not result from differences in oocyte hydration. Haddock generally fast during the spawning season and therefore depletion of available yolk reserves is a probable cause of reduced egg size in late-season batches (Houghton et al. 1985, Bromley et al. 1986, Kjesbu et al. 1990). In addition, batch fecundity and total egg dry weight per batch were inversely related to batch number, suggesting that maternal investment in reproduction decreases between first and final egg batches on both a per egg and per batch basis. In contrast, Ouellet et al. 


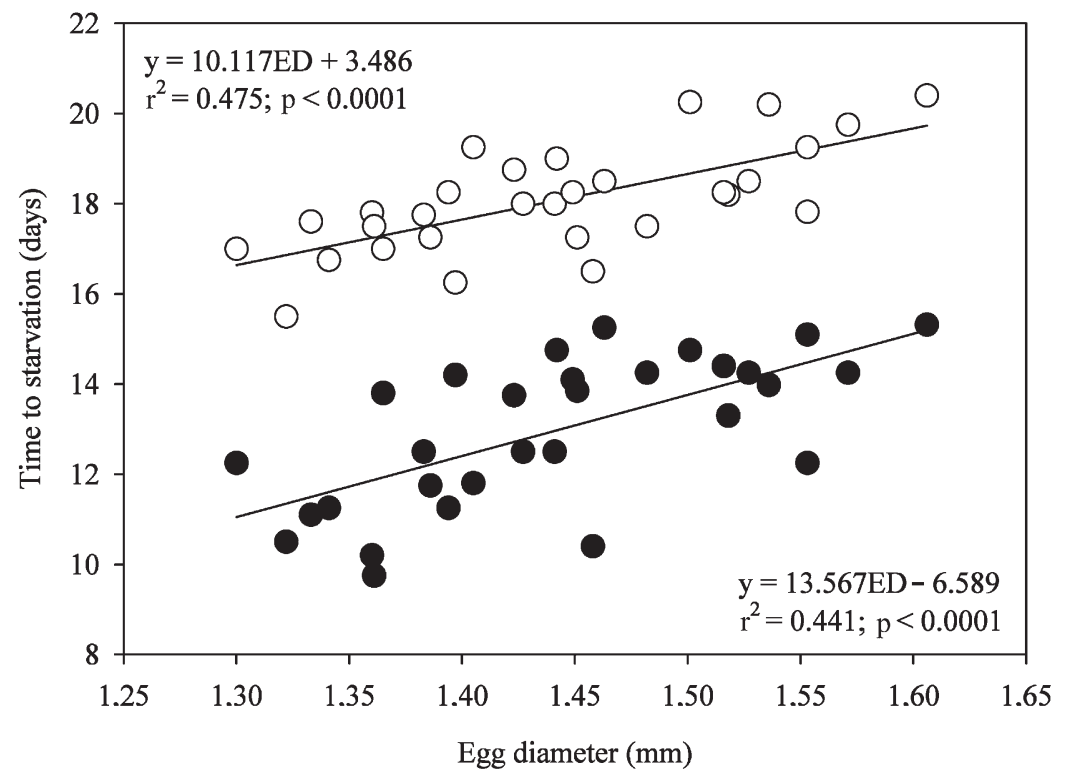

Fig. 5. Melanogrammus aeglefinus. Relationship between egg diameter (ED) and time to $50(\bullet)$ and $95 \%(O)$ mortality due to starvation for larvae incubated at $5^{\circ} \mathrm{C}$

(2001) reported that the dry weight of entire egg batches for Atlantic cod did not decline throughout the spawning season. An increase in water temperature throughout the spawning season has also been implicated in the seasonal decrease in egg size for serial spawners (Ware 1975, Tanasichuk \& Ware 1987, Chambers 1997), but could not account for changes in egg size in the present study since temperatures were maintained relatively constant.

Despite attempts to maximize fertilization success by matching females with males of similar body size, batch fertilization success within and among pairs was highly variable (0 to $100 \%$ ). Since both haddock and Atlantic cod of much greater size than the ones used in the present study have spawned successfully in these tanks in the past (R. M. Rideout unpubl. data), it is believed that tank size did not hinder spawning in any way and therefore did not contribute to low or variable fertilization success. Moksness \& Selvik (1987) reported fertilization rates primarily greater than $80 \%$ for haddock from the Norwegian Skagerrak coast, but analyzed egg batches from communal spawning tanks, where multiple males had the opportunity to fertilize each egg batch. In addition, it is unclear if the egg-collection system used by Moksness \& Selvik (1987) was capable
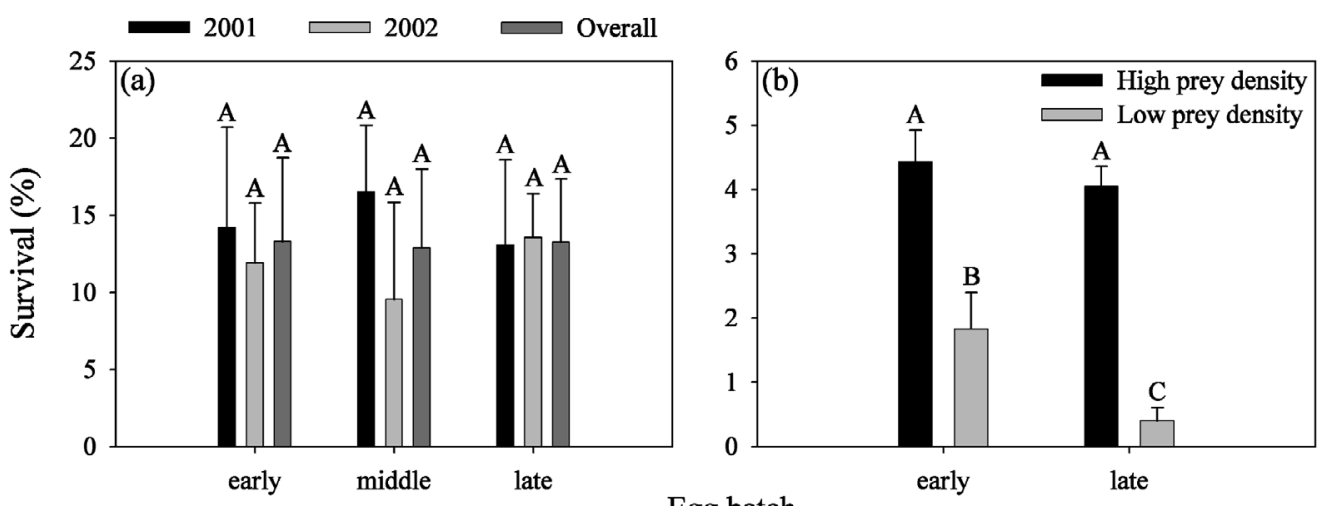

Egg batch

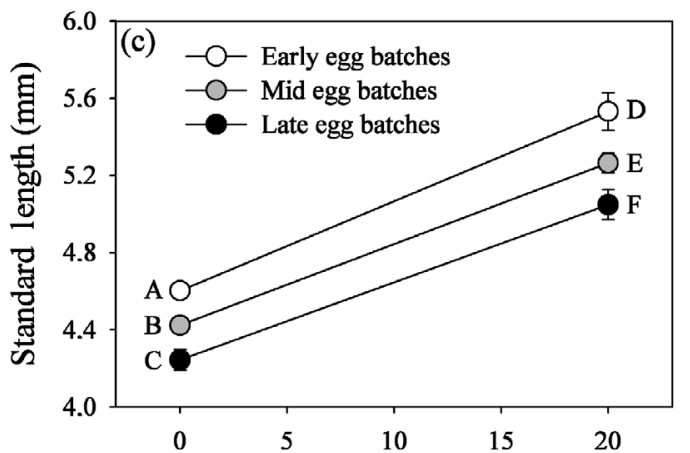

Fig. 6. Melanogrammus aeglefinus. Mean $( \pm \mathrm{SE})$ survival and growth of larvae incubated at $7^{\circ} \mathrm{C}$ : survival of (a) early-, midand late-season larvae under high prey density in 2001 and 2002, and (b) of early-, and late-season larvae under high and low prey density in 2003; standard length of (c) earlymid- and late-season larvae under high prey density in 2001 and 2002, and (d) of early- and lateeason larvae under high and low prey density in 2003. Bars and data points with same letter are not significantly different 
of collecting negatively buoyant unfertilized eggs. Failure to account for these eggs would lead to an overestimation of fertilization success.

Hatching success was variable and fell primarily within the 30 to $70 \%$ range observed by Moksness \& Selvik (1987). Neither fertilization success nor hatching success were related to batch number, confirming previous suggestions (Rideout et al. 2004b) that the seasonal decrease in haddock egg size is not accompanied by a decrease in egg quality (where egg quality represents the potential of an egg to produce a viable offspring). Egg size also does not appear to influence hatching success for brook trout (Hutchings 1991) or Atlantic cod (Nissling et al. 1998, Ouellet et al. 2001). A comprehensive review of marine and estuarine fishes revealed no relationship between egg size and cumulative or daily egg mortality rates (Pepin 1991).

The strong positive relationship observed between egg size and larval size has been reported for numerous other fishes (see reviews by Heyer et al. 2001, Ouellet et al. 2001, Browman et al. 2003). We also demonstrated strong relationships between egg size and other larval traits that may influence survival, including myotome height, jaw size, eye size and finfold area. Larger eggs also produced larvae with greater yolk reserves and these larvae survived longer without food, perhaps providing a survival advantage during periods of low or variable food abundance. The effects of egg size on larval morphology are evident for at least the first $5 \mathrm{~d}$ following hatching. In the feeding studies, the initial differences in larval standard length between early (large) eggs and late (small) eggs were still evident after $20 \mathrm{~d}$. It is uncertain if these initial size differences persist into later life stages. Initial differences in larval morphology due to egg size have been reported to persist for up to $140 \mathrm{~d}$ for Arctic charr (Wallace \& Aasjord 1984) and for up to 8 mo for Atlantic salmon (Glebe et al. 1979). In Siberian sturgeon Acipenser baeri, initial differences in larval size persisted for up to $20 \mathrm{~d}$, but disappeared during the juvenile stage (Gisbert et al. 2000), and in rainbow trout fry, initial size differences disappeared by 4 wk after the first feeding (Springate \& Bromage 1985). Kjørsvik et al. (1990) suggested that large egg size likely does not infer any long-term growth or survival advantage in fishes.

Larval survival in the high prey density treatment was lower in 2003 than 2001 and 2002. In 2003, rearing tanks had a continuous flow-through supply of seawater, which probably resulted in continuous loss of prey items through the drain. In 2001 and 2002, however, inadequate temperature control of incoming water prevented the use of a continuous flow-through system. Instead, the water in the tanks was only exchanged twice daily (prior to feeding), which kept prey at high densities for a longer period of time. Results of the 2003 feeding study confirmed that larval growth and survival increased with increasing prey density. Similar reports have been made previously for haddock as well as Atlantic mackerel, sand lance and Atlantic cod (Buckley et al. 1987, Puvanendran \& Brown 1999). Even at high-prey levels, haddock larvae had relatively low survivorship and growth rates, a phenomenon that appears to be characteristic of this species in captivity. Downing \& Litvak $(1999 a, b)$ reported survivorship of 0.3 to $3.8 \%$ for haddock larvae reared on rotifers under various light treatments, while Buckley et al. (1987) reported higher survivorship (15 to $35 \%$ ) for larvae reared on wild zooplankton. Growth rates for haddock larvae in the high-prey treatments fell within the range of growth rates ( 0.7 to $\left.1.1 \% \mathrm{SL} \mathrm{d}^{-1}\right)$ previously reported for this species (Buckley et al. 1987, Downing \& Litvak 1999a, b). Haddock larvae may grow faster in the ocean ( 7 to $13 \%$ dry wt d $\mathrm{d}^{-1}$ : Buckley \& Lough 1987 ) than in captivity (0.7 to $4.7 \%$ dry wt d ${ }^{-1}$ : Laurence 1974 , Buckley et al. 1987, Moksness \& Selvik 1987) and faster in large basins $\left(2.7 \%\right.$ dry wt $\left.\mathrm{d}^{-1}\right)$ than in small rearing tanks ( $0.7 \%$ dry wt $\mathrm{d}^{-1}$ : Moksness \& Selvik 1987).

In the high prey density treatment, there was no difference in survival or growth for haddock larvae produced at different times throughout the spawning season. Studies with other fish species also suggest that larger egg and larval sizes do not result in improved survival at high prey densities (Hutchings 1991, McEvoy \& McEvoy 1991, Gisbert et al. 2000, Jónsson \& Svavarsson 2000). When prey density was low, however, survival of larvae from early-season egg batches was significantly greater than those from lateseason batches. The results suggest that, when prey is abundant, both large and small larvae are capable of feeding successfully and therefore achieve similar growth and survival. However, when prey abundance is reduced, smaller larvae may be disadvantaged by inferior searching- and prey-capturing capabilities. We acknowledge that the actual differences in survival for early- and late-season larvae were not large, but nonetheless they were statistically significant and even small differences in larval mortality have the potential to have large impacts on recruitment (Houde 1989). Hutchings (1991) reported that decreased food abundance increased mortality among juvenile brook trout from small eggs but had a negligible effect on those from the largest eggs.

Differences in larval morphology and early life history success between successive egg batches from the same female were attributed to the seasonal decline in egg size. However, important determinants of egg quality, such as yolk fatty acid levels, were not monitored. Differences in egg quality are most commonly reported to influence fertilization and hatching success, but can also influence early life history traits after 
hatching. For example, eggs with reduced levels of docosahexaenoic acid (DHA) produce larvae that have low growth rates, perhaps due to poor vision and diminished feeding success (Masuda 2003). Using the paired-spawning setup with a serial spawning species such as haddock allowed us to control for parental genetics but not seasonal changes in yolk composition. A method to manipulate yolk size in order to get different sized larvae from the same egg batch (Jardine \& Litvak 2003) could alleviate this problem, but would limit the number of eggs that could be analyzed.

The results of this study have important consequences for aquaculture and recruitment in wild fish stocks. For aquaculture purposes, the decrease in haddock egg size with successive batch number and the resulting changes in larval morphology are of no concern, since prey density is typically kept high. In the ocean, egg size and fitness appear to be closely linked to the plankton production cycle. For haddock, the decline in egg size throughout the spawning season is paralleled by an increase in plankton density. Our results suggest that the smaller larvae produced late in the spawning season are viable when prey density is high, but that viability may be reduced in years when late-season plankton density is low. Hislop (1988) suggested that to determine the annual egg production of North Sea haddock, a weighting factor could be used to account for the small, supposedly low-viability eggs produced by precocious females. More work is needed in order to determine if such a weighting factor could also be applied to small eggs produced by haddock late in the spawning season.

Acknowledgements. S. Neil assisted in allocating broodstock to paired-spawning tanks and provided valuable insight into haddock larviculture practices. H. Browman, A. B. Skiftesvik, S. Rideout and 3 anonymous reviewers provided useful comments on an earlier version of the manuscript. Financial support was provided by the Canadian Biotechnology Strategy (E.A.T.), Fisheries and Oceans Canada (E.A.T.), and the Natural Sciences and Engineering Research Council of Canada (M.K.L.: NSERC Discovery and CRD grants; R.M.R.: NSERCPGSB).

\section{LITERATURE CITED}

Bromley PJ, Sykes PA, Howell BR (1986) Egg production of turbot (Scophthalmus maximus L.) spawning in tank conditions. Aquaculture 53:287-293

Browman HI, St-Pierre JF, Skiftesvik AB, Racca RG (2003) Behaviour of Atlantic cod (Gadus morhua) larvae: an attempt to link maternal condition with larval quality. In: Browman HI, Skiftesvik AB (eds) The big fish bang. Proceedings of the 26th Annual Larval Fish conference. Institute of Marine Research, Bergen, p 71-95

Buckley LJ, Lough RG (1987) Recent growth, biochemical composition, and prey field of larval haddock (Melanogrammus aeglefinus) and Atlantic cod (Gadus morhua) on Georges Bank. Can J Fish Aquat Sci 44:14-25
Buckley LJ, Halavik TA, Smigielski AS, Laurence GC (1987) Growth and survival of the larvae of three species of temperate marine fishes reared at discrete prey densities. Am Fish Soc Symp 2:82-92

Chambers RC (1997) Environmental influences on egg and propagule sizes in marine fishes. In: Chambers RC, Trippel EA (eds) Early life history and recruitment in fish populations. Chapman \& Hall, London, p 63-102

Downing G, Litvak MK (1999a) The effect of photoperiod, tank colour and light intensity on growth of larval haddock. Aquacult Int 7:1-14

Downing G, Litvak MK (1999b) The influence of light intensity on growth of larval haddock. N Am J Aquacult 61:135-140

Gisbert E, Williot P, Castelló-Orvay F (2000) Influence of egg size on growth and survival of early stages of Siberian sturgeon (Acipenser baeri) under small scale hatchery conditions. Aquaculture 183:83-94

Glebe BD, Appy TD, Saunders RL (1979) Variation in Atlantic salmon (Salmo salar) reproductive traits and their implications in breeding programs. Int Counc Explor Sea Comm Meet 1979/M 23

Heyer CJ, Miller TJ, Binkowski FP, Caldarone EM, Rice JA (2001) Maternal effects as a recruitment mechanism in Lake Michigan yellow perch (Perca flavescens). Can J Fish Aquat Sci 58:1477-1487

Hinckley S (1990) Variation of egg size of walleye pollock Theragra chalcogramma with a prelininary examination of the effect of egg size on larval size. Fish Bull US Dep Comm 88:471-483

Hislop JRG (1975) The breeding and growth of whiting, Merlangus merlangus, in captivity. J Cons Int Explor Mer 36: 119-127

Hislop JRG (1988) The influence of maternal length and age on the size and weight of the eggs and the relative fecundity of the haddock, Melanogrammus aeglefinus, in British waters. J Fish Biol 32:923-930

Hislop JRG, Robb AP, Gauld JA (1978) Observations on effects of feeding level on growth and reproduction in haddock, Melanogrammus aeglefinus (L.) in captivity. J Fish Biol 13:85-98

Houde ED (1989) Subtleties and episodes in the early life of fishes. J Fish Biol 35(Suppl A):29-38

Houghton RG, Last JM, Bromley PJ (1985) Fecundity and egg size of sole (Solea solea (L.)) spawning in captivity. J Cons Int Explor Mer 42:162-165

Hutchings JA (1991) Fitness consequences of variation in egg size and food abundance in brook trout Salvelinus fontinalis. Evolution 45:1162-1168

Jardine D, Litvak MK (2003) Direct yolk sac volume manipulation of zebrafish embryos and the relationship between offspring size and yolk sac volume. J Fish Biol 63:388-397

Jónsson B, Svavarsson E (2000) Connection between egg size and early mortality in Arctic charr, Salvelinus alpinus. Aquaculture 187:315-317

Kjesbu OS (1989) The spawning activity of cod, Gadus morhua L. J Fish Biol 34:195-206

Kjesbu OS, Witthames PR, Solemdal P, Greer Walker M (1990) Ovulatory rhythm and a method to determine the stage of spawning in Atlantic cod (Gadus morhua). Can J Fish Aquat Sci 47:1185-1193

Kjørsvik E, Mangor-Jensen A, Holmefjord I (1990) Egg quality in fishes. Adv Mar Biol 26:71-113

Laurence GC (1974) Growth and survival of haddock (Melanogrammus aeglefinus) larvae in relation to planktonic prey concentration. J Fish Res Board Can 31: 1415-1419

Masuda R (2003) The critical role of docosahexaenoic acid in 
marine and terrestrial ecosystems: from bacteria to human behavior. In: Browman HI, Skiftesvik AB (eds) The big fish bang. Proceedings of the 26th Annual Larval Fish Conference, Institute of Marine Research, Bergen, p 249-256

McEvoy LA, McEvoy J (1991) Size fluctuations in the eggs and newly hatched larvae of captive turbot (Scophthalmus maximus). J Mar Biol Assoc UK 71:679-690

Meekan MG, Fortier L (1996) Selection for fast growth during the larval life of Atlantic cod Gadus morhua on the Scotian Shelf. Mar Ecol Prog Ser 137:25-37

Moksness E, Selvik JR (1987) Description of the spawning and the early life history of haddock (Melanogrammus aeglefinus L.) from the Norwegian Skagerrak coast. Flødevigen Rapp 1:1-15

Nissling A, Larsson R, Vallin L, Frohlund K (1998) Assessment of egg and larval viability in cod, Gadus morhua: methods and results from an experimental study. Fish Res 38: 169-186

Ojanguren AF, Reyes-Gavilán FG, Braña F (1996) Effects of egg size on offspring development and fitness in brown trout, Salmo trutta L. Aquaculture 147:9-20

Ouellet P, Lambert Y, Bérubé I (2001) Cod egg characteristics and viability in relation to low temperature and maternal nutritional condition. ICES J Mar Sci 58:672-686

Pepin P (1991) Effect of temperature and size on development, mortality, and survival rates of the pelagic early life history stages of marine fish. Can J Fish Aquat Sci 48:503-518

Puvanendran V, Brown JA (1999) Foraging, growth and survival of Atlantic cod larvae reared in different prey concentrations. Aquaculture 175:77-92

Rakitin A, Ferguson MM, Trippel EA (2001) Male reproduc-

Editorial responsibility: Otto Kinne (Editor-in-Chief), Oldendorf/Luhe, Germany tive success and body size in Atlantic cod Gadus morhua L. Mar Biol 138:1077-1085

Rideout RM, Trippel EA, Litvak MK (2004a) Paternal effects on haddock early life history traits. J Fish Biol 64:695-701

Rideout RM, Trippel EA, Litvak MK (2004b) Predicting haddock embryo viability based on early cleavage patterns. Aquaculture 230:215-228

Springate JRC, Bromage NR (1985) Effects of egg size on early growth and survival in rainbow trout (Salmo gairdneri Richardson). Aquaculture 47:163-172

Tanasichuk RW, Ware DM (1987) Influence of interannual variations in winter sea temperature of fecundity and egg size in Pacific herring (Clupea harengus pallasi). Can J Fish Aquat Sci 44:1485-1495

Thorpe JE, Miles MS, Keay DS (1984) Developmental rate, fecundity and egg size in Atlantic salmon, Salmo salar L. Aquaculture 43:289-305

Trippel EA (1998) Egg size and viability and seasonal offspring production of young Atlantic cod. Trans Am Fish Soc 127:339-359

Wallace JC, Aasjord D (1984) An investigation of the consequences of egg size for the culture of Arctic charr, Salvelinus alpinus (L.). J Fish Biol 24:427-435

Ware DM (1975) Relation between egg size, growth, and natural mortality of larval fish. J Fish Res Board Can 32: $2503-2512$

Winer BJ (1971) Statistical principles in experimental design. McGraw Hill, New York

Zonova AS (1973) The connection between egg size and some of the characters of female carp (Cyprinus carpio L.). J Ichthyol 13:679-689

Submitted: November 13, 2003; Accepted: August 19, 2004

Proofs received from author(s): December 20, 2004 